\title{
KOMOLY SIKERRE CSAK ELHIVATOTT MUNKA RÉVÉN SZÁmíthatunk - INTERJú DAle A. MARTin-NAL SZOLNOKI DÁNIEL ${ }^{1}$
}

A Corvinus Egyetem megújulása részeként a Köz-Gazdaság egy olyan interjúsorozatot indított el, amelynek célja az üzleti szférában komoly sikereket elért szereplök, magas beosztású vezetők megszólaltatása és tapasztalataik összegyüjtése annak érdekében, hogy hallgatóink elsö kézböl kapjanak a sikeres pályakezdésüket segítö információkat. A mai beszélgetésünk házigazdája Dale A. Martin, a Siemens Zrt. elnök-vezérigazgatója. Martin úr az amerikai Pennsylvania államban született, MBA-val egyenértékü diplomáját a bécsi Wirtschaftsuniversität-en szerezte. 2010 óta áll a hazai Siemens élén, miközben a nemzetközi Siemens-csoportnál már 28 éve dolgozik. Kiemelkedö szerepe van a német-magyar gazdasági kapcsolatok ápolásában: a Német-Magyar Ipari és Kereskedelmi Kamara elnöki pozícióját a maximálisan kitölthetö három cikluson, azaz hat éven át töltötte be.

Szolnoki Dániel: Martin úr, elöször is szeretném megköszönni, hogy időt szakított ránk. Meggyöződésünk, hogy az ilyen személyes beszélgetések olyan betekintést nyúithatnak egy sikeres karrierbe, ami egy fiatal pályakezdő részére egyébként elérhetetlen lenne. Mit gondol, milyen tulajdonságok szükségesek egy olyan sikeres üzleti karrierhez, mint például az Öné?

Dale A. Martin: A kérdés az, hogy kinek mi számít sikeres karriernek. Van, aki saját vállalkozást szeretne, vagy freelancerként szeretne érvényesülni. Illetve vannak, akik nem szeretnének vezető pozícióba kerülni, mert jól érzik magukat egy megbecsült szakértői szerepben is. Tehát azt, hogy mit tekinthetünk sikeres karriernek, mindig az egyéni célokhoz kell mérni.

Ha mégis szeretnénk általánosan érvényes tapasztalatokat leszürni, akkor a sikerhez három alapvető készséget tartok szükségesnek. Fontos, hogy az illető szorgalmas legyen és kitartó abban, amit csinál. Másrészt szükséges egyfajta kíváncsiság, az újdonságokra való nyitottság. Legyünk kíváncsiak nem csupán a körülöttünk lévő világra, hanem önmagunkra is, ilyen módon fedezzük fel a saját erősségeinket, illetve a fejlesztendő területeinket is. Mindez nagyban segíti azt, hogy egy-egy kritikus pont során pozitív alternatívákat tudjunk találni. Végezetül nem lehet eléggé hangsúlyozni a kommunikáció, és ezen belül a nyelvtudás szerepét, ami a mai globalizált üzleti környezetben egy szükséges, de messze nem elégséges készség.

Ha az embernek vannak céljai, és a fenti tényezők megvalósulnak, akkor nagy az esély arra, hogy fel tudja ismerni a munkája során esetlegesen kínálkozó lehetőségeket.

Szolnoki Dániel: A mai világban számtalan lehetőség kínálkozik egy fiatal pályakezdő elött, ezért közülük sokan nem is feltétlenül tudják azonnal eldönteni, hogy mibe érdemes belevágniuk. Mit tanácsol, milyen szempontokat érdemes mérlegelni annak érdekében, hogy egy fiatal minél hamarabb megtalálja a számára leginkább megfelelő irányt?

\footnotetext{
${ }^{1}$ egyetemi hallgató, Budapesti Corvinus Egyetem

DOI:10.14267/RETP2019.04.27
} 
Dale A. Martin: Fontos kiemelni a kellő mértékű önismeretet, mert az a fiatal munkavállaló, aki alapvetően tisztában van a képességeivel és az általa elérni kívánt célokkal, majdnem biztosan olyan döntést hoz, ami hosszútávon is az érdekeit szolgálja. A kellö mértékü önismeret megszerzésére kiváló lehetőség az egyetemi tanulmányok időszaka, mert itt könnyen és különösebb rizikó nélkül kipróbálhatjuk magunkat különböző feladatokban, szerepkörökben.

Szolnoki Dániel: Ezek szerint úgy gondolja, hogy az önismeret fejlesztésének egyfajta tárgyként, önálló diszciplínaként is meg kellene jelennie az egyetemi képzésben?

Dale A. Martin: Az egyetem hatékonyan tud ahhoz hozzájárulni, hogy a hallgató az ott eltöltött 3-5 év során tapasztalatokat szerezzen, ebben például a tanórákon kívüli egyéb tevékenységeknek nagy szerepe van. Az én esetemben egyetemi hallgatóként aktívan dolgoztam az AIESEC-ben, ami komoly segítséget jelentett abban, hogy rájöjjek, mi is érdekel igazán, és kipróbáljam magam egyfajta „vezetői szerepben”.

Szolnoki Dániel: A Corvinus Egyetemen hagyományosan nagy szerepe van a diákszervezeti mozgalmaknak. Ezek szerint Ön is úgy látja, hogy ezek értékes kiegészítői a hagyományos oktatásnak?

Dale A. Martin: Határozottan így gondolom. Ezek a mozgalmak olyan lehetőségeket kínálnak a fiataloknak, ahol különböző feladatokat végezhetnek, és megismerhetnek másokat. Kipróbálhatják például, hogy milyen vezetői képességekkel rendelkeznek, miként tudnak kommunikálni másokkal, illetve mennyire hatékonyan tudnak meggyőzni másokat. Ezen tapasztalatok révén könnyebben kikristályosodik, hogy hol, milyen területen vannak erősségeik.

Szolnoki Dániel: A saját tapasztalataim szerint az ilyen diákszervezetek sikeres múködtetése időnként nagy áldozatokat is igényelhet a tagoktól. Azzal, hogy az ember minden szabad idejét ebben a közösségben éli, gyakran érezheti úgy, hogy emiatt lemond más dolgokról. Ön szerint egy ilyen közösségben rejlö potenciális erő és a kapcsolati tőke valóban megér ekkora áldozatot?

Dale A. Martin: Nem gondolom, hogy az "áldozat” a megfelelő kifejezés. Véleményem szerint ez is egyfajta befektetés a jövőbe.

A munkával kapcsolatban gyakran felmerül a "work-life balance” kérdése, azaz a munka és a magánélet egyensúlya. A munkánk sikeressége nem független attól, hogy mennyit invesztálunk bele: ha valaki egy munkát teherként él meg, az előbb-utóbb úgyis kiderül, és az illetőnek rá kell jönnie, hogy az hosszútávon nem fenntartható. Viszont aki a munkáját egyfajta pozitív élményként éli meg, a sikert is ilyen visszajelzésnek tekinti. Tehát "more input generates more output", vagyis komoly sikerre csak elhivatott munka révén számíthatunk. Természetesen a munkánk hatékonysága egy további kérdés.

Szolnoki Dániel: Visszatérve az egyetemi évekre, mit gondol, egyénileg milyen készségek elsajátítására érdemes időt és energiát áldozni?

Dale A. Martin: Az egyik legfontosabb a nyelvtudás fejlesztése. Ennek szerepe a mai világban elengedhetetlen. A Siemens és az osztrák-magyar gyökereim miatt is úgy vélem, hogy nemcsak az angol, hanem a német nyelvismeret is kiemelten értékes Magyarországon. Az angol a világ nyelve, de Magyarország egy gyakorlatilag 100-millió fős német nyelvterülettel határos. Ez a német nyelvterület pedig müszaki és gazdasági fontossággal bír, még Európán túlmenően is. 
Szolnoki Dániel: Nyilván a speciális, szakmai nyelvismeret jelentősége felértékelődig, amit elsősorban külföldi tanulmányutak révén szerezhetünk meg. Személyesen milyen jelentősége volt az egyéni karrierjében az ilyen utaknak?

Dale A. Martin: Esetemben az angol és a német az otthoni környezet miatt adott volt. Azt már hamar felismertem, hogy a munkaerőpiacon akkor válok egyedivé, ha valamilyen különleges nyelvet is elsajátítok. A kínai nyelv kiválasztásában közvetett módon a családom segített: bár édesapám japánul is beszélt, nekem már akkor meggyőződésem volt, hogy "Japán a jelen és a Kína a jövő". Éppen ezért elutaztam Tajvanra, ahol ösztöndíj hiányában angol nyelv tanításából fedeztem a költségeimet. Ez egyben egy önismereti tréning is volt, ami megerősített abban, hogy egy teljesen idegen országban önmagamat is el tudom tartani, illetve képes vagyok érvényesülni. A német-angol és kínai-magyar nyelvtudásom nélkül biztos vagyok abban, hogy nem jutottam volna odáig, ahol most vagyok. Ezt a nyelvtudást valódi környezetben, a gyakorlat révén szereztem meg, ami nem sikerülhetett volna a kellő mennyiségű befektetett energia nélkül.

Szolnoki Dániel: Az említett kompetenciák fejlesztésén túlmenően tapasztalatai szerint a cégek számára mi jelenti a legnagyobb kihívást a friss pályakezdőkkel kapcsolatban?

Dale A. Martin: Természetesen, ahogy az előző generációk, ők is rövid idő alatt szeretnék megváltani a világot. A mai fiatal pályakezdők számára kinyílt a világ, rengeteg információval rendelkeznek, minden nehézség nélkül utazhatnak. A sok lehetőségből és az információáramlás felgyorsulásából következően minden közelinek és elérhetőnek tünik. Sok mindent kipróbálnak, gyorsan, kötöttségek nélkül képesek állást, céget váltani, ha valahol nem találják meg a számításukat. Ezért cégvezetőként meggyőződésem, hogy ezeket a fiatalokat sok esetben orientálni kell. Be kell számukra mutatni a cégen belüli perspektívákat és rá kell mutatni arra, hogy milyen sokszínü, érdekes feladatokkal foglalkozhatnak nálunk. Tapasztalataink szerint így lehet őket hosszabb távon is megtartani, és értékes szaktudással rendelkező kollégává kinevelni. Persze azt is figyelembe kell vennünk, hogy az egyes generációk értékrendje más lehet az őket megelőző generációkhoz képest.

Szolnoki Dániel: Tapasztalata szerint mit jelentenek ezek a más értékek? Például mi a legnagyobb különbség a mai és a 10 évvel ezelőtt belépett friss pályakezdők hozzáállásában?

Dale A. Martin: Az életünk folyamatosan változik, például a legszükségesebb készségek rangsora is állandó mozgásban van, ahogy azt a World Economic Forum felmérése („Top 10 skills 2015 vs. 2020”) is dokumentálta. Ezzel párhuzamosan az eltérő korú dolgozók is más dolgokat részesítenek előnyben. Manapság pl. a rugalmas munkaidő, az oldott munkahelyi légkör, a szervezeti kultúra, illetve a mobilitás elsődleges szempontokká váltak. Ezzel szemben korábban fontosabb volt a munkavállalók biztonságérzete és a hosszabb távú kiszámíthatóság. Jó lenne, ha ez megmaradhatna, mert ez a légkör csak egy jó gazdasági környezetben megvalósítható.

Szolnoki Dániel: Az állandó változásban felismerhető egyfajta ciklikusság? El tudja azt képzelni, hogy a most fontosnak vélt rugalmas munkaidő helyett egy újabb gazdasági válság következtében pl. a biztonságérzet újra felértékelödik?

Dale A. Martin: Talán a ciklikusság nem feltétlenül pontos kifejezés erre a jelenségre, hiszen idővel nem ugyanoda jutunk vissza. Abban egyetértek, hogy egyfajta „szezonalitás” mindenképpen megfigyelhető. Például 5 évvel ezelőtt is más volt a helyzet, és ezek alapján könnyü elképzelni, hogy ezek a prioritások, akár 5 éven belül is megváltoznak és a ma másodlagosnak tekintett szempontok újra fontossá válnak. 
Szolnoki Dániel: Végezetül szeretném kihangsúlyozni azt, hogy számunkra milyen egyedülálló lehetőséget jelent az ilyen topmenedzserekkel történő közvetlen kommunikáció. De talán az Ön számára is érdekes lehetőség az új generációval való direkt kapcsolat. Ezt a csatornát megragadva, van-e esetleg olyan "take home message" tapasztalata, amit szívesen megosztana velünk?

Dale A. Martin: Talán legjobb az, ha mindenki igyekszik megtalálni a saját útját. Ez nem feltétlen látszik azonnal, de előbb-utóbb a felkészült ember megtalálja. A dolgunk csupán annyi, hogy lehetöség szerint a legtöbb energiát fektessük a munkánkba és figyeljünk oda a környezetünkre. A siker nem biztos, hogy azonnal érkezik, de a kitartás hosszútávon megtérül. Fontos látni, hogy a cél az elöttünk álló kihívások megoldása, amit lehet, hogy csak valamilyen alternatív próbálkozás révén tudunk elérni. Lehetöség szerint legyen egy tervünk, és ahelyett, hogy rögtön a nagy végcélnak vágnánk neki, bontsuk kisebb rész-célokra, és ezek mentén haladjunk fokozatosan, kitartóan.

Szolnoki Dániel: Köszönjük az interjút! 